\title{
Humanitarian evidence summary
}

\section{No.14}

\author{
Luke Kelly \\ University of Manchester \\ May 2021
}

This is the 14th monthly Humanitarian Evidence Summary (HUMES) to signpost FCDO and other UK government departments to the latest relevant evidence and discourse on humanitarian action to inform and support their response. It is the result of 1 day of work per month and is not intended to be a comprehensive summary of available evidence on humanitarian action but aims to make original documents easily accessible to decision-makers that, if relevant to them, they could refer to before making decisions.

\section{Enhancing protection and humanitarian access}

\begin{tabular}{|l|l|l|l|l|}
\hline Publication & Title/URL & $\begin{array}{l}\text { Author(s)/Journal/ } \\
\text { Publication type }\end{array}$ & Summary & $\begin{array}{l}\text { HoP } \\
\text { Top } \\
\text { eads }\end{array}$ \\
\hline April 2021 & $\begin{array}{l}\text { Over troubled } \\
\text { waters: } \\
\text { maritime } \\
\text { rescue } \\
\text { operations in } \\
\text { the Central 16. } \\
\text { Mediterranean } \\
\text { Route }\end{array}$ & $\begin{array}{l}\text { Eugenio } \\
\text { Cusumano and } \\
\text { Matteo Villa; } \\
\text { Institute of } \\
\text { Migration; book } \\
\text { chapter }\end{array}$ & $\begin{array}{l}\text { Analyses the role of search and } \\
\text { rescue operations in the } \\
\text { Mediterranean and border } \\
\text { enforcements. The 'findings suggest } \\
\text { that SAR operations by European } \\
\text { authorities and NGOs have played } \\
\text { an important role in reducing the } \\
\text { deadliness of sea crossings without } \\
\text { significantly contributing to } \\
\text { incentivizing irregular }\end{array}$ & $\begin{array}{l}\text { migration.' } \\
\text { April 2021 }\end{array}$ \\
$\begin{array}{l}\text { The impact of } \\
\text { covid-19 on } \\
\text { humanitarian } \\
\text { access }\end{array}$ & $\begin{array}{l}\text { Rebecca } \\
\text { Brubaker, Adam } \\
\text { Day and Sophie } \\
\text { Huvé; United } \\
\text { Nations University; } \\
\text { report }\end{array}$ & $\begin{array}{l}\text { Analyses humanitarian access } \\
\text { restrictions arising from covid-19 } \\
\text { during March-November 2020, as } \\
\text { well as the relationships between } \\
\text { different actors in the humanitarian } \\
\text { sphere. It also shows the impacts of }\end{array}$ & & \\
\hline
\end{tabular}




\begin{tabular}{|c|c|c|c|}
\hline & & & $\begin{array}{l}\text { reduced access, adaptations made, } \\
\text { and provides recommendations. }\end{array}$ \\
\hline April 2021 & $\begin{array}{l}\text { Humanitarian } \\
\text { Access } \\
\text { SCORE } \\
\text { Report: Tigray, } \\
\text { Ethiopia and } \\
\text { Global } \\
\text { database of } \\
\text { humanitarian } \\
\text { organisations }\end{array}$ & $\begin{array}{l}\text { Abby Stoddard, } \\
\text { Paul Harvey, } \\
\text { Monica Czwarno } \\
\text { and Meriah-jo } \\
\text { Breckenridge; } \\
\text { Humanitarian } \\
\text { Outcomes; Report } \\
\text { Humanitarian } \\
\text { Outcomes, } \\
\text { database }\end{array}$ & $\begin{array}{l}\text { Findings from a telephone survey of } \\
614 \text { people in the Tigray region of } \\
\text { Ethiopia between } 17 \text { February and } 8 \\
\text { March } 2021 \text {, as well as interviews. It } \\
\text { finds a large majority in need of aid, } \\
\text { and access constraints. } \\
\text { Database developed as part of } \\
\text { CORE initiative on national and } \\
\text { international humanitarian } \\
\text { organisations, arranged by state of } \\
\text { HQ, countries of operation, size, } \\
\text { organisation type, sector, and }\end{array}$ \\
\hline $\begin{array}{l}\text { March } \\
2021\end{array}$ & $\begin{array}{l}\text { Conflict } \\
\text { Sensitivity } \\
\text { Analysis: } \\
\text { United Nations } \\
\text { Mission in } \\
\text { South Sudan } \\
\text { (UNMISS) } \\
\text { Protection of } \\
\text { Civilian (PoC) } \\
\text { Sites } \\
\text { Transition: } \\
\text { Bentiu, Unity } \\
\text { State, and } \\
\text { Malakal, Upper } \\
\text { Nile State }\end{array}$ & $\begin{array}{l}\text { Conflict Sensitivity } \\
\text { Resource Facility; } \\
\text { report }\end{array}$ & $\begin{array}{l}\text { Looks at conflict sensitivity } \\
\text { considerations for protection of } \\
\text { civilian (PoC) sites in South Sudan, } \\
\text { in light of the withdrawal of UN } \\
\text { forces. It focused on Bentiu and } \\
\text { Malakal, where there is a history of } \\
\text { inter-communal violence. }\end{array}$ \\
\hline $\begin{array}{l}27 \text { April } \\
2021\end{array}$ & $\begin{array}{l}\text { Urban warfare: } \\
\text { an age-old } \\
\text { problem in } \\
\text { need of new } \\
\text { solutions }\end{array}$ & $\begin{array}{l}\text { Laurent Gisel et al; } \\
\text { ICRC Law \& Policy } \\
\text { blog }\end{array}$ & $\begin{array}{l}\text { The first blog in a new series on } \\
\text { urban warfare. Outlines the reasons } \\
\text { for increased urban warfare, its } \\
\text { costs, the stance of IHL, and how } \\
\text { civilians can e better protected. }\end{array}$ \\
\hline
\end{tabular}




\begin{tabular}{|l|l|l|l|}
22 April & $\begin{array}{l}\text { A common } \\
\text { enemy: } \\
\text { aggregating } \\
\text { intensity in non- } \\
\text { international } \\
\text { armed conflicts }\end{array}$ & $\begin{array}{l}\text { Chiara Redaelli; } \\
\text { ICRC Law \& Policy } \\
\text { blog }\end{array}$ & $\begin{array}{l}\text { Considers new ways of determining } \\
\text { how violence involving many non- } \\
\text { state armed groups can be } \\
\text { characterised in legal terms. } \\
\text { Designating a 'non-international } \\
\text { conflict' means IHL applies, but in } \\
\text { cases where multiple armed groups } \\
\text { are operating, this may not be } \\
\text { applied. It suggests that 'aggregating } \\
\text { intensity' of fighting is a more } \\
\text { accurate way of determining whether } \\
\text { there is a conflict, and thereby } \\
\text { appropriately applying IHL. }\end{array}$ \\
\hline April 2021 & $\begin{array}{l}\text { The pandemic's } \\
\text { impact on } \\
\text { global conflict } \\
\text { and } \\
\text { demonstration } \\
\text { trends }\end{array}$ & ACLED; report & $\begin{array}{l}\text { Report outlining conflict and } \\
\text { demonstration trends, with links to } \\
\text { country specific reports. }\end{array}$ \\
\hline
\end{tabular}

\section{Needs assessment and analysis}

\begin{tabular}{|c|c|c|c|c|}
\hline $\begin{array}{l}\text { Publication } \\
\text { date }\end{array}$ & Title/URL & $\begin{array}{l}\text { Author(s)/Journal/ } \\
\text { Publication type }\end{array}$ & Summary & rop \\
\hline $\begin{array}{l}12 \text { April } \\
2021\end{array}$ & $\begin{array}{l}\text { Violence } \\
\text { Against Women } \\
\text { and } \\
\text { Children During } \\
\text { COVID-19- } \\
\text { One Year On } \\
\text { and } 100 \text { Papers } \\
\text { In }\end{array}$ & $\begin{array}{l}\text { Shelby Bourgault, } \\
\text { Amber Peterman } \\
\text { and Megan } \\
\text { O'Donnell; Center } \\
\text { for Global } \\
\text { Development; } \\
\text { literature review }\end{array}$ & $\begin{array}{l}\text { Discusses } 26 \text { papers on violence } \\
\text { against women and children in low- } \\
\text { and middle-income countries since } \\
\text { December } 2020 \text {. Most report } \\
\text { increases in violence, with lost } \\
\text { income seen to increase the risk. Few } \\
\text { evaluate interventions. }\end{array}$ & \\
\hline April 2021 & $\begin{array}{l}\text { Risk } \\
\text { communication } \\
\text { and community } \\
\text { engagement } \\
\text { (RCCE) }\end{array}$ & U-LEARN; report. & $\begin{array}{l}\text { Focused on refugee communities } \\
\text { during covid-19. If finds that } \\
\text { information about covid- } 19 \text { is } \\
\text { available, but some data on infection } \\
\text { and death rates is missing, and some }\end{array}$ & \\
\hline
\end{tabular}




\begin{tabular}{|l|l|l|l|} 
& $\begin{array}{l}\text { assessment: } \\
\text { Uganda } 2020\end{array}$ & $\begin{array}{l}\text { groups report barriers to information. } \\
\text { Radios are the most common source } \\
\text { of information. }\end{array}$ \\
\hline April 2021 & $\begin{array}{l}\text { Impact of } \\
\text { Social } \\
\text { Inequalities and } \\
\text { Discrimination } \\
\text { on Vulnerability } \\
\text { to Crises }\end{array}$ & $\begin{array}{l}\text { Becky Carter; } \\
\text { K4D; literature } \\
\text { review }\end{array}$ & $\begin{array}{l}\text { Reviews the literature on the effect of } \\
\text { social inequalities and discrimination } \\
\text { on vulnerability to crises. It focuses } \\
\text { on inequalities among groups in } \\
\text { society arising from the discrimination } \\
\text { of people based on their gender; age; } \\
\text { disability; sexual orientation, gender } \\
\text { identity and/or expression, and sex } \\
\text { characteristics; and religious belief. It } \\
\text { finds that certain groups are more } \\
\text { vulnerable to crises and less able to } \\
\text { access humanitarian aid. }\end{array}$ \\
\hline
\end{tabular}

\section{Accountability to affected populations}

\begin{tabular}{|c|c|c|c|c|}
\hline $\begin{array}{l}\text { Publication } \\
\text { date }\end{array}$ & Title/URL & $\begin{array}{l}\text { Author(s)/Journal/ } \\
\text { Publication type }\end{array}$ & Summary & Top \\
\hline $\begin{array}{l}20 \text { April } \\
2021\end{array}$ & $\begin{array}{l}\text { Everyone's } \\
\text { doing stuff but } \\
\text { nobody's } \\
\text { accountable - } \\
\text { will Grand } \\
\text { Bargain } 2.0 \text { set } \\
\text { us right? }\end{array}$ & $\begin{array}{l}\text { Nick van Praag } \\
\text { and Meg Settler; } \\
\text { ODI HPN; blog }\end{array}$ & $\begin{array}{l}\text { Argues that current attempts at } \\
\text { accountability to affected populations } \\
\text { (AAP) are limited in scope and } \\
\text { application. A more meaningful form } \\
\text { of AAP would be based on a 'results } \\
\text { culture'. The authors recommend a } \\
\text { longer 24-month programme cycle, } \\
\text { and a participatory review as a } \\
\text { precondition for inclusion in the } \\
\text { Global Humanitarian Overview. }\end{array}$ & \\
\hline $\begin{array}{l}22 \text { April } \\
2021\end{array}$ & $\begin{array}{l}\text { Opinion: What's } \\
\text { wrong with the } \\
\text { humanitarian } \\
\text { aid system - } \\
\text { and how to fix it }\end{array}$ & $\begin{array}{l}\text { Mark Lowcock; } \\
\text { Devex blog and } \\
\text { CGDEV webinar }\end{array}$ & $\begin{array}{l}\text { Recommends reforms including a } \\
\text { 'three-year pilot of an Independent } \\
\text { Commission for Voices in Crises to } \\
\text { hold the system to account.' It would } \\
\text { issue reports on needs, grade } \\
\text { humanitarian response plans and } \\
\text { publish interim and final evaluations. } \\
\text { He emphasises that it should be }\end{array}$ & \\
\hline
\end{tabular}




\begin{tabular}{|l|l|l|l|l|}
\hline & & & $\begin{array}{l}\text { genuinely independent and } \\
\text { transparent. }\end{array}$ & \\
\hline 10 April & $\begin{array}{l}\text { Healthcare } \\
\text { governance } \\
\text { during } \\
\text { humanitarian } \\
\text { responses: a } \\
\text { survey of } \\
\text { current practice } \\
\text { among } \\
\text { international } \\
\text { humanitarian } \\
\text { actors }\end{array}$ & $\begin{array}{l}\text { Prudence Jarrett } \\
\text { et al; Conflict and } \\
\text { Health; journal } \\
\text { article. }\end{array}$ & $\begin{array}{l}\text { It finds limited accountability for } \\
\text { international humanitarian actors' } \\
\text { public health practice. Governance } \\
\text { activities are inconsistently applied. It } \\
\text { is based on humanitarian actors' } \\
\text { healthcare governance practice and } \\
\text { interviews with senior health } \\
\text { professionals. There is a need for } \\
\text { consensus on governance. Despite } \\
\text { covid being seen as a threat, } \\
\text { behaviour change is limited. }\end{array}$ & \\
\hline
\end{tabular}

\section{Cash programming}

\begin{tabular}{|c|c|c|c|c|}
\hline $\begin{array}{l}\text { Publication } \\
\text { date }\end{array}$ & Title/URL & $\begin{array}{l}\text { Author(s)/Journal/ } \\
\text { Publication type }\end{array}$ & Summary & Top \\
\hline & $\begin{array}{l}\text { Towards } \\
\text { shock- } \\
\text { responsive } \\
\text { social } \\
\text { protection }\end{array}$ & Maintains; reports. & $\begin{array}{l}\text { Examines social protection } \\
\text { programmes in Bangladesh, } \\
\text { Ethiopia, Kenya, Pakistan, Sierra } \\
\text { Leone and Uganda, and how } \\
\text { they have responded to Covid- } \\
\text { 19. Looks at national and } \\
\text { humanitarian responses and } \\
\text { their effects; how the responses } \\
\text { were operationalised; and } \\
\text { several types of outcome. }\end{array}$ & \\
\hline $\begin{array}{l}1 \text { April } \\
2021\end{array}$ & $\begin{array}{l}\text { Cashing in: } \\
\text { Turning } \\
\text { challenges into } \\
\text { opportunities } \\
\text { when } \\
\text { evaluating } \\
\text { humanitarian } \\
\text { cash } \\
\text { assistance }\end{array}$ & $\begin{array}{l}\text { N Dillon et al; } \\
\text { CaLP/ALNAP; } \\
\text { report }\end{array}$ & $\begin{array}{l}\text { Discusses the challenges of } \\
\text { evaluating cash transfers. } \\
\text { Findings on: the outcomes of } \\
\text { multipurpose cash transfers; } \\
\text { outcomes for markets and } \\
\text { multiplier effects; the role of cash } \\
\text { coordination mechanisms; } \\
\text { collaboration in cash assistance: } \\
\text { the impact of operational } \\
\text { models; linkages between cash }\end{array}$ & \\
\hline
\end{tabular}




\begin{tabular}{|c|c|c|c|}
\hline & & & $\begin{array}{l}\text { assistance and social protection; } \\
\text { working with private sector } \\
\text { partners in the delivery of cash } \\
\text { transfers; efficiency and cost- } \\
\text { effectiveness }\end{array}$ \\
\hline April 2021 & $\begin{array}{l}\text { Social } \\
\text { Protection at } \\
\text { the } \\
\text { Humanitarian- } \\
\text { Development } \\
\text { Nexus: } \\
\text { Insights from } \\
\text { Yemen }\end{array}$ & $\begin{array}{l}\text { Yashodhan } \\
\text { Ghorpade and Ali } \\
\text { Ammar; World } \\
\text { Bank papers }\end{array}$ & $\begin{array}{l}\text { Compares humanitarian and } \\
\text { development social protection } \\
\text { programmes in Yemen. Includes } \\
\text { data on recipients and area. It } \\
\text { finds considerable convergence } \\
\text { and blurring between the two. It } \\
\text { also finds likely exclusion of } \\
\text { many poor households. It } \\
\text { suggests ways humanitarian and } \\
\text { development actors can } \\
\text { cooperate. }\end{array}$ \\
\hline $\begin{array}{l}15 \text { April } \\
2021\end{array}$ & $\begin{array}{l}\text { Seven years of } \\
\text { Cash and } \\
\text { Voucher } \\
\text { Assistance: } \\
\text { Parting words } \\
\text { of wisdom } \\
\text { from two } \\
\text { amazing } \\
\text { CaLPies } \\
+ \\
\text { A short history } \\
\text { of cash and } \\
\text { voucher } \\
\text { assistance }\end{array}$ & $\begin{array}{l}\text { Nathalie Klein and } \\
\text { Sophie Tholstrup; } \\
\text { CaLP; blog and } \\
\text { podcast }\end{array}$ & $\begin{array}{l}\text { Blog discussing changes in cash } \\
\text { programming over the past } 7 \\
\text { years. They note the widespread } \\
\text { acceptance of cash, but the } \\
\text { continued need for localisation } \\
\text { and demand-led delivery, as well } \\
\text { as more mitigation of digital } \\
\text { risks. }\end{array}$ \\
\hline April 2021 & $\begin{array}{l}\text { Cash\&Voucher } \\
\text { Assistance } \\
\text { for Health: a } \\
\text { case study } \\
\text { from Jordan }\end{array}$ & Medair; report & $\begin{array}{l}\text { Report on the effect of Medair's } \\
\text { cash transfers in } 2017-2019 \text { on } \\
\text { health in vulnerable refugee and } \\
\text { host populations in Jordan. } \\
\text { Recommendations include the } \\
\text { need for standard definitions of } \\
\text { 'quality care' and monitoring }\end{array}$ \\
\hline
\end{tabular}




\begin{tabular}{|l|l|l|} 
& $\mid \begin{array}{l}\text { tools; and to consider the } \\
\text { integration of refugees into the } \\
\text { national health insurance } \\
\text { scheme. }\end{array}$ \\
\hline
\end{tabular}

\section{Managing risk better, preparedness and anticipation}

\begin{tabular}{|c|c|c|c|c|}
\hline $\begin{array}{l}\text { Publication } \\
\text { date }\end{array}$ & Title/URL & $\begin{array}{l}\text { Author(s)/Journal/ } \\
\text { Publication type }\end{array}$ & Summary & $\begin{array}{l}\text { Top } \\
\text { reads }\end{array}$ \\
\hline April 2021 & $\begin{array}{l}\text { 2020: the non- } \\
\text { covid year in } \\
\text { disasters }\end{array}$ & $\begin{array}{l}\text { United Nations } \\
\text { Office for Disaster } \\
\text { Risk Reduction; } \\
\text { report }\end{array}$ & $\begin{array}{l}\text { Provides data from the EM-DAT } \\
\text { database. Finds that disasters in } \\
2020 \text { were worse than average } \\
\text { in terms of number and cost, but } \\
\text { with fewer deaths. }\end{array}$ & \\
\hline $\begin{array}{l}\text { March } \\
2021\end{array}$ & $\begin{array}{l}\text { Saving lives } \\
\text { and livelihoods: } \\
\text { The benefits of } \\
\text { investments } \\
\text { in climate } \\
\text { change } \\
\text { adaptation and } \\
\text { resilience }\end{array}$ & $\begin{array}{l}\text { Sophie Dicker, } \\
\text { Sam Unsworth, } \\
\text { Rebecca Byrnes } \\
\text { and Bob Ward; } \\
\text { Grantham Institute } \\
\text { on Climate } \\
\text { Change and the } \\
\text { Environment; } \\
\text { Report. }\end{array}$ & $\begin{array}{l}\text { Six case studies of successful } \\
\text { climate change adaptation and } \\
\text { resilience, in the UK, Kenya, } \\
\text { Mozambique, India (2) and } \\
\text { Vietnam. Analyses reasons for } \\
\text { success, effects and lessons. }\end{array}$ & \\
\hline April 2021 & $\begin{array}{l}\text { A case for } \\
\text { transformation } \\
? \\
\text { The longer- } \\
\text { term } \\
\text { implications of } \\
\text { the covid-19 } \\
\text { pandemic }\end{array}$ & $\begin{array}{l}\text { UN Global } \\
\text { Humanitarian } \\
\text { Policy Forum; } \\
\text { report }\end{array}$ & $\begin{array}{l}\text { Report based on the December } \\
2020 \text { forum. Concludes that } \\
\text { greater preparedness for } \\
\text { systemic problems is needed, as } \\
\text { well as more preparedness; } \\
\text { localisation; diversity and } \\
\text { inclusion; the responsible use of } \\
\text { digital technologies and } \\
\text { collaboration across siloes are all } \\
\text { needed. }\end{array}$ & \\
\hline April 2021 & $\begin{array}{l}\text { Reducing the } \\
\text { humanitarian fi } \\
\text { nancing gap: } \\
\text { review of }\end{array}$ & $\begin{array}{l}\text { Barnaby Willitts- } \\
\text { King and } \\
\text { Alexandra } \\
\text { Spencer; }\end{array}$ & $\begin{array}{l}\text { Reports on the UN's } 2016 \\
\text { Humanitarian Financing Panel's } \\
\text { recommendations to reduce } \\
\text { need by bringing more }\end{array}$ & \\
\hline
\end{tabular}




\begin{tabular}{|c|c|c|c|}
\hline & $\begin{array}{l}\text { progress since } \\
\text { the report of } \\
\text { the High-Level } \\
\text { Panel on } \\
\text { Humanitarian } \\
\text { Financing }\end{array}$ & $\begin{array}{l}\text { Overseas } \\
\text { Development } \\
\text { Institute; Report }\end{array}$ & $\begin{array}{l}\text { development finance into crisis } \\
\text { situations; and attract more } \\
\text { donors. Finds that progress on } \\
\text { reducing need is uneven, and } \\
\text { limited on widening the resource } \\
\text { base. Recommends a focused } \\
\text { approach in the short-term. }\end{array}$ \\
\hline April 2021 & $\begin{array}{l}\text { International } \\
\text { Development } \\
\text { Association } \\
\text { (IDA) } \\
\text { Countries: } \\
\text { Resilience and } \\
\text { Disaster Risk } \\
\text { Management } \\
\text { Stories }\end{array}$ & $\begin{array}{l}\text { World } \\
\text { Bank/GFDRR; } \\
\text { report }\end{array}$ & $\begin{array}{l}\text { Brief stories of successful } \\
\text { disaster risk reduction in various } \\
\text { countries. }\end{array}$ \\
\hline April 2021 & $\begin{array}{l}\text { The climate crisis } \\
\text { and humanitarian } \\
\text { need: taking } \\
\text { action to support } \\
\text { the world's most } \\
\text { vulnerable } \\
\text { communities }\end{array}$ & $\begin{array}{l}\text { Sorcha } \\
\text { O'Callaghan, Mark } \\
\text { Lowcock and } \\
\text { Fonteh Akum; ODI } \\
\text { HPG Webinar } \\
\text { recording w }\end{array}$ & $\begin{array}{l}\text { Discussion of the impact of climate } \\
\text { change in the world's most vulnerable } \\
\text { places, and what needs to be done } \\
\text { about it (including strong reference to } \\
\text { anticipatory finance). }\end{array}$ \\
\hline
\end{tabular}

\section{Resilience and protracted crisis}

\begin{tabular}{|l|l|l|l|l|}
\hline $\begin{array}{l}\text { Publication } \\
\text { date }\end{array}$ & Title/URL & $\begin{array}{l}\text { Author(s)/Journal/ } \\
\text { Publication type }\end{array}$ & Summary & Top \\
fo21 & $\begin{array}{l}\text { Deads } \\
\text { actors at the } \\
\text { nexus: Lessons } \\
\text { from crises in } \\
\text { Bangladesh, } \\
\text { Cameroon and } \\
\text { Somalia }\end{array}$ & $\begin{array}{l}\text { Charlotte } \\
\text { MacDiarmid, } \\
\text { Sarah Dalrymple } \\
\text { and Sarah } \\
\text { Hanssen; Food } \\
\text { and Agriculature } \\
\text { Organization, } \\
\text { Development } \\
\text { Initiatives and } \\
\text { Norwegian }\end{array}$ & $\begin{array}{l}\text { Analyses humanitarian- } \\
\text { development-peace cooperation } \\
\text { on issues of: 1) partnerships and } \\
\text { strategy, 2) coordination and } \\
\text { joined-up planning, 3) } \\
\text { programming, 4) financing and 5) } \\
\text { organizational issues. }\end{array}$ & \\
\hline
\end{tabular}




\begin{tabular}{|c|c|c|c|}
\hline & & $\begin{array}{l}\text { Refugee Council; } \\
\text { report }\end{array}$ & \\
\hline $\begin{array}{l}2 \text { April } \\
2021\end{array}$ & $\begin{array}{l}\text { The Politics of } \\
\text { Return: } \\
\text { Understanding } \\
\text { Trajectories of } \\
\text { Displacement } \\
\text { and the } \\
\text { Complex } \\
\text { Dynamics of } \\
\text { 'Return' in } \\
\text { Central and } \\
\text { East Africa }\end{array}$ & $\begin{array}{l}\text { Anna Macdonald } \\
\text { and Holly Porter, } \\
\text { eds.; Journal of } \\
\text { Refugee Studies; } \\
\text { special issue }\end{array}$ & $\begin{array}{l}\text { Noting that few forcibly displaced } \\
\text { persons return to their country of } \\
\text { origin or are resettled, the } \\
\text { articles use a number of case } \\
\text { studies from Central and East } \\
\text { Africa. }\end{array}$ \\
\hline April 2021 & $\begin{array}{l}\text { Managing the } \\
\text { journey out of } \\
\text { violent } \\
\text { extremism in } \\
\text { the Lake Chad } \\
\text { Basin }\end{array}$ & $\begin{array}{l}\text { Fonteh Akum, } \\
\text { Remadji Hoinahty } \\
\text { and Malik Samuel; } \\
\text { Institute for } \\
\text { Security Studies; } \\
\text { report. }\end{array}$ & $\begin{array}{l}\text { Based on interviews with ex- } \\
\text { Boko Haram associates and peer } \\
\text { group non-associates, as well as } \\
\text { stakeholders involved in policy. } \\
\text { Reasons for disengagement are } \\
\text { based on circumstances, } \\
\text { opportunity and expectations. It } \\
\text { finds that programmes do not } \\
\text { address women } \\
\text { comprehensively, or the regional } \\
\text { nature of the crisis. }\end{array}$ \\
\hline April 2021 & $\begin{array}{l}\text { "I could not } \\
\text { sleep while they } \\
\text { were hungry": } \\
\text { Investigating } \\
\text { the role of } \\
\text { social networks } \\
\text { in Yemen's } \\
\text { humanitarian } \\
\text { crisis }\end{array}$ & $\begin{array}{l}\text { Jeeyon Janet King } \\
\text { et al; Feinstein } \\
\text { International } \\
\text { Center; Report }\end{array}$ & $\begin{array}{l}\text { The initial findings on the role of } \\
\text { social networks as a source of } \\
\text { support in Yemen. Shows that } \\
\text { they are crucial, but are under } \\
\text { pressure from the conflict. } \\
\text { Humanitarian aid has helped } \\
\text { maintain networks, but } \\
\text { sometimes has prompted } \\
\text { tensions. }\end{array}$ \\
\hline
\end{tabular}




\section{Other}

\begin{tabular}{|c|c|c|c|c|}
\hline $\begin{array}{l}\text { Publication } \\
\text { date }\end{array}$ & Title/URL & $\begin{array}{l}\text { Author(s)/Journal/ } \\
\text { Publication type }\end{array}$ & Summary & $\begin{array}{l}\text { Top } \\
\text { reads }\end{array}$ \\
\hline April 2021 & $\begin{array}{l}\text { From digital } \\
\text { promise to } \\
\text { frontline } \\
\text { practice: new } \\
\text { and emerging } \\
\text { technologies } \\
\text { in } \\
\text { humanitarian } \\
\text { action }\end{array}$ & $\begin{array}{l}\text { Leonie Arendt- } \\
\text { Cassetta; } \\
\text { UNOCHA; report }\end{array}$ & $\begin{array}{l}\text { Outlines the opportunities and } \\
\text { challenges of new and emerging } \\
\text { technologies: Al and predictive } \\
\text { analytics; mobile applications and } \\
\text { social media; digital cash transfers; } \\
\text { crisis maps; biometrics; UAVs; } \\
\text { blockchain; internet of things; 3D } \\
\text { printing. }\end{array}$ & \\
\hline April 2021 & $\begin{array}{l}\text { Epidemics } \\
\text { that didn't } \\
\text { happen }\end{array}$ & $\begin{array}{l}\text { Preventepidemics. } \\
\text { com; website }\end{array}$ & $\begin{array}{l}\text { Website with lessons from } \\
\text { successfully controlled epidemics in } \\
\text { low- and middle-income countries, } \\
\text { including several examples of covid } \\
\text { suppression }\end{array}$ & \\
\hline $\begin{array}{l}15 \text { April } \\
2021\end{array}$ & $\begin{array}{l}\text { Sharing the } \\
\text { Keys to the } \\
\text { Localization } \\
\text { House }\end{array}$ & $\begin{array}{l}\text { Oheneba Boateng } \\
\text { and Claudia } \\
\text { Meier; GPPI; blog }\end{array}$ & $\begin{array}{l}\text { Argues that donors, UN agencies } \\
\text { and international NGOs' incentive } \\
\text { structures work against real } \\
\text { localisation. They argue for a } \\
\text { Localization Index to objectively } \\
\text { evaluate efforts. }\end{array}$ & \\
\hline
\end{tabular}

\section{Resource Hubs}

\begin{tabular}{|l|l|l|}
\hline Title/URL & Author/Organisation & Summary \\
\hline COVID-19 Data Explorer: & $\begin{array}{l}\text { Humanitarian Data } \\
\text { Exchange (HDX) } \\
\text { Global Humanitarian }\end{array}$ & $\begin{array}{l}\text { World map of covid cases and } \\
\text { various vulnerability and socio- } \\
\text { economic risk factors (including } \\
\text { vaccine rollout, food security, school } \\
\text { closures, CERF allocations etc.). }\end{array}$ \\
\hline
\end{tabular}




\begin{tabular}{|c|c|c|}
\hline $\begin{array}{l}\text { Covid-19 and } \\
\text { Humanitarian Crises }\end{array}$ & $\begin{array}{l}\text { Johns Hopkins Center for } \\
\text { Humanitarian Health, } \\
\text { Health in Humanitarian } \\
\text { Crises Centre, London } \\
\text { School of Hygiene and } \\
\text { Tropical Medicine and } \\
\text { Geneva Centre of } \\
\text { Humanitarian Studies, } \\
\text { The Graduate Institute of } \\
\text { International and } \\
\text { Development Studies and } \\
\text { the University of Geneva }\end{array}$ & $\begin{array}{l}\text { Website for the exchange of field- } \\
\text { based COVID-19 programme } \\
\text { adaptations and innovations. }\end{array}$ \\
\hline $\begin{array}{l}\text { Covid-19 Mobility Impact } \\
\text { Reports }\end{array}$ & UN IOM & $\begin{array}{l}\text { Frequently updated reports on } \\
\text { migration restrictions. }\end{array}$ \\
\hline$\frac{\text { IDMC Internal }}{\text { Displacement Updates }}$ & $\begin{array}{l}\text { Internal displacement } \\
\text { monitoring centre }\end{array}$ & Global data on internal displacement \\
\hline ACAPS Crisis in Sight & ACAPS & $\begin{array}{l}\text { Global overview of crisis, including } \\
\text { covid and conflict; as well as access } \\
\text { constraints. }\end{array}$ \\
\hline $\begin{array}{l}\text { CVA and COVID-19: } \\
\text { resources, guidance, } \\
\text { events and questions }\end{array}$ & CaLP & $\begin{array}{l}\text { Guidance and resources on covid } \\
\text { and cash transfers }\end{array}$ \\
\hline $\begin{array}{l}\text { IASC: COVID-19 } \\
\text { Outbreak Readiness and } \\
\text { Response guidance }\end{array}$ & $\begin{array}{l}\text { Inter-Agency Standing } \\
\text { Committee }\end{array}$ & $\begin{array}{l}\text { IASC principles and protocols } \\
\text { adapted to covid- } 19\end{array}$ \\
\hline $\begin{array}{l}\text { OCHA } \\
\text { COVID19 Resource } \\
\text { Material }\end{array}$ & $\begin{array}{l}\text { Office for the Coordination } \\
\text { of Humanitarian Affairs }\end{array}$ & $\begin{array}{l}\text { A wide range of guidance and } \\
\text { resources from WHO, IASC, the EU, } \\
\text { IFRF and others, as well as country- } \\
\text { specific information. }\end{array}$ \\
\hline $\begin{array}{l}\text { Humanitarian Data } \\
\text { Exchange: COVID-19 } \\
\text { Pandemic in Locations }\end{array}$ & $\begin{array}{l}\text { Humanitarian Data } \\
\text { Exchange (HDX) }\end{array}$ & $\begin{array}{l}\text { Global data on infections and deaths; } \\
\text { a list of data sets on cases and } \\
\text { prevention/mitigation measures. }\end{array}$ \\
\hline
\end{tabular}




\begin{tabular}{|c|c|c|}
\hline $\begin{array}{l}\text { with a Humanitarian } \\
\text { Response }\end{array}$ & & \\
\hline $\begin{array}{l}\text { Humanitarian Data } \\
\text { Exchange: Government } \\
\text { Measures Dataset }\end{array}$ & $\begin{array}{l}\text { Humanitarian Data } \\
\text { Exchange (HDX) }\end{array}$ & $\begin{array}{l}\text { Global data on government covid-19 } \\
\text { measures under } 5 \text { categories: Social } \\
\text { distancing; Movement restrictions; } \\
\text { Public health measures; Social and } \\
\text { economic measures; Lockdowns. }\end{array}$ \\
\hline $\begin{array}{l}\text { IEG Lesson Library: } \\
\text { Evaluative Resources and } \\
\text { Evidence to inform the } \\
\text { COVID-19 Response }\end{array}$ & $\begin{array}{l}\text { World Bank Independent } \\
\text { Evaluation Group }\end{array}$ & $\begin{array}{l}\text { A library of Evaluative Resources and } \\
\text { Evidence to inform the COVID-19 } \\
\text { Response }\end{array}$ \\
\hline $\begin{array}{l}\text { Relief Web: regional topic } \\
\text { pages for Covid-19 } \\
\text { and global topic pages }\end{array}$ & Relief Web & $\begin{array}{l}\text { Regional and global reports and } \\
\text { resources on humanitarian needs } \\
\text { and response. }\end{array}$ \\
\hline $\begin{array}{l}\text { IASC Accountability and } \\
\text { Inclusion Resources } \\
\text { Portal }\end{array}$ & $\begin{array}{l}\text { Inter-Agency Standing } \\
\text { Committee }\end{array}$ & $\begin{array}{l}\text { A library of resources on } \\
\text { accountability and inclusion. }\end{array}$ \\
\hline $\begin{array}{l}\text { Attacked and Threatened: } \\
\text { Health care targeted in } \\
\text { conflict and COVID- } \\
\text { 19https://www.covid19hu } \\
\text { manitarian.com/ }\end{array}$ & Insecurity Insight & $\begin{array}{l}\text { Map of violence and threats against } \\
\text { health care across the world. }\end{array}$ \\
\hline
\end{tabular}




\section{Suggested citation}

Kelly, L. (2021). Monthly Humanitarian Evidence Summary No.14. K4D Helpdesk Report. Brighton, UK: Institute of Development Studies. DOI: 10.19088/K4D.2021.069

\section{Methodology}

Given the wide range of topics covered, this monthly summary includes guidelines, blogs, news articles, dashboards, data, and editorials, in addition to policy and academic literature. The sources included are found through searches of academic literature, humanitarian think tanks, resource hubs and NGO websites. The searches are restricted to articles published in the previous month, in English. This is complemented by email recommendations from FCDO advisors and leading experts. This is trial and error approach, which will be refined and changed over the coming weeks. If you have literature to include in the weekly summary, please email - luke.kelly@manchester.ac.uk.

\section{About this report}

The monthly Humanitarian Evidence Summaries are not intended to replace professional advice and the researcher or the K4D consortium cannot be held responsible for any decisions made on the basis of the summaries alone.

K4D services are provided by a consortium of leading organisations working in international development, led by the Institute of Development Studies (IDS), with Education Development Trust, Itad, University of Leeds Nuffield Centre for International Health and Development, Liverpool School of Tropical Medicine (LSTM), University of Birmingham International Development Department (IDD) and the University of Manchester Humanitarian and Conflict Response Institute (HCRI).

This humanitarian evidence summary was prepared for the UK Government's Foreign, Commonwealth and Development Office (FCDO) and its partners in support of pro-poor programmes. Except where otherwise stated, it is licensed for non-commercial purposes under the terms of the Open Government Licence v3.0. K4D cannot be held responsible for errors, omissions or any consequences arising from the use of information contained in this humanitarian evidence summary. Any views and opinions expressed do not necessarily reflect those of $F C D O, K 4 D$ or any other contributing organisation.

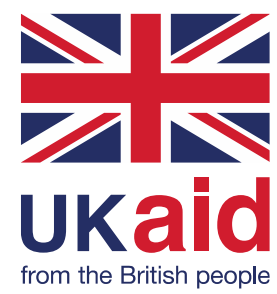

(C) Crown copyright 2021. 